\title{
The Role of Secretaries in the Adaptation to New Habits
}

\author{
Asa Dian Novianti ${ }^{*}$, Caecilia Tri Wahyanti ${ }^{2}$
}

1,2 Universitas Kristen Satya Wacana, Salatiga, Indonesia

\section{A R T I C L E IN F O}

\section{Article history:}

Received September 20, 2021

Revised September 21, 2021

Accepted October 302021

Available online November 25, 2021

\section{Keywords:}

Secretary, Difficulties, Tasks, Applications, Skills

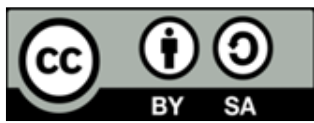

This is an open access article under the CC BY-SA license.

Copyright (C) 2021 by Author. Published by Universitas Pendidikan Ganesha.

\begin{abstract}
A B S T R A C T
During the adaptation period to new habits, he faced two new work systems that caused the company secretary to experience difficulties due to changes in the company. These changes lead to further tasks and new technologies that secretaries must reach in helping managers to facilitate lessons. This study aims to identify the difficulties encountered in adapting to new habits, how to use them during the application, the applications used to complete assignments, and the skills needed by secretaries in the adaptation era. This research was conducted using qualitative research methods. Data were collected from interviews with three secretaries from three different companies. The findings show several obstacles, including delays experienced due to the rules of working from home, the obligation to carry out by following health protocols, and being responsible for health protocols in the workplace. In the running, these secretaries use various applications, such as Microsoft Office, Zoom or WebEx, and E-Archive tools. Therefore, they are expected to be able to utilize technology, be detail-oriented, have administrative skills, operate computers, and communicate in English. This research is expected to be helpful by increasing the knowledge of future secretaries who plan to work during new habits and office management studies.
\end{abstract}

\section{INTRODUCTION}

The COVID-19 pandemic has changed the fabric of human social life. The COVID-19 pandemic has created unplanned social changes because it causes disorganization in all areas of human life (Dewantara \& Nurgiansah, 2020; Maulana, 2021; Onyema, 2020; Yuzulia, 2021). All forms of policies that are implemented are generally known as policies. In implementing the procedure, an activity must be planned and carried out seriously based on certain norms to achieve specific goals (Putra, 2021; Wuarlela, 2020). Thus, everyone called it "new normal" or "new life order" (Prahmana et al., 2021; Sutarna et al., 2021). This adaptation to new habits is implemented in the essential sectors, such as places of worship, markets, restaurants, hotels, private and public transportations, and workplaces (Antee, 2021; Hanik, 2020). With the beginning of the adaptation to new habits in workplaces, new regulations arose. One of those is the work-from-home and the work-from-office policy. Secretarial duties actually cannot be separated from company confidentiality. The initial policy that the leadership or company will issue will be known by the secretary (Dwihartanti \& Nur Faizah, 2019; Selfiana, 2019). The secretary's job is to help the leader in lightening his duties. The secretary plays an essential role in helping to keep secrets and keep the secrets of the company's leadership because at least many secrets are known by the secretary to guard against anyone interested in him constantly (Aw et al., 2016; Nafiah, 2016). Secretary is a person who is closely related to written activities or taking notes from an office or company activity. To become a professional secretary, every secretary must carry some requirements. If a secretary does not have the requirements to become a secretary, then the duties and functions of the secretary cannot run properly. The conditions that must be met by a secretary to become a professional secretary are understanding the company, having relevant knowledge, mastering the language well, and being able to carry out tasks (Aw et al., 2016; Mardiyah et al., 2018).

During the implementation of the new habits in workplaces, secretaries as someone who hold an essential role in assisting, guiding, and preparing the needs of the manager as their right hand and has a considerable influence in improving the quality of the company must be able adapt with changes to the work system (Maulana, 2021; Saifulloh \& Darwis, 2020; Sufriadi, 2019). The Changes in the company's work system lead to new tasks and new technologies that a secretary must understand in assisting managers in facilitating their duties (Cugno et al., 2022; Galanakis et al., 2021; Saputra et al., 2022). This changes causing the secretary to have some difficulty either in terms of work or adapting to health 
protocols. With changes due to the new habit adaptation period, the secretary must hone his skills to be able to survive in the period of adaptation of new habits and can help improve the manager's duties (Xu et al., 2021; Zhao \& Rau, 2020).

Based on the results of pre-research interviews conducted with the secretary at PT. ISTW, he mentioned that he had adjusted to a new habit and felt uncomfortable following the protocol and washing his hands at the start of a new habit. Meanwhile, based on the results of the interview, it was found that there was a new task of administering Swab tests and PCR tests for employees and executives that he had to do. Nowadays, it is compulsory for a secretary to possess critical thinking skills, problem solving skills, and listening skills (Astuti, 2020; Dewi \& Octavia, 2017). Currently a secretary is required to have critical thinking skills, problem solving skills, and listening skills (Kristiyanti, 2016; Nafiah, 2016; Rosidah \& Arantika, 2019). Furthermore, a secretary has to be knowledgeable, open-minded, and well-informed about the growing business markets. Previous research found that the ten state-owned enterprises being tested, they wanted their secretaries to have the competency to have efficient time management skills, flexibility, positive organizational culture, communication ability, and a score of at least 400 in TOEFL (Selfiana, 2018). However, the research did not examine the difficulties that secretaries encountered during the adaptation to the new habits, the completion of secretaries' tasks during the adaptation to the new normal era, and the utilization of supporting applications to carry out tasks during the adaptation to new habits. The skills that secretaries will need during the adaptation to the new normal era had also not been revealed in the study.

This research attempts to analyze the difficulties experienced by secretaries, the secretaries' tasks, the applications that they used, and the skills they needed in the adaptation to new habits. The research's purpose is to find out their difficulties, to reveal the completion of their tasks, to discover what applications they used, and to identify what skills they are required to have in the adaptation of a new normal era. This research is expected to benefit by improving the knowledge of future secretaries planning to work during the new habits and the office management study. It is also hoped to provide insights related to tasks, applications, and skills needed by secretaries while adapting to new habits and be a medium to broaden the knowledge gained in college.

\section{METHODS}

This research was analyzed using the qualitative research approach. Qualitative research is a research employed to understand the phenomenon that the subjects experienced, such as their behaviors, perceptions, motivations, and actions, in a form of a description using words and languages, in a specific and natural context with the use of various scientific methods (Moleong, 2005). This method was applied for its capability in answering the research problems and the ease in collecting the research data to answer the research questions. Interviews were conducted to collect the data Interview is a conversation with a certain purpose, the conversation is done with two parties, namely the interviewer and interviewer (Moleong, 2005). The research analyzed primary data gathered through in-depth interviews. The interviews were done with three secretaries who had applied the new habits adaptation in their workplaces.

Research participant data comes from the company PT. Berca Handayaperkasa, PT. Indofood CBP Sukses Mandiri, PT. ISTW. Triangulation technique was used to validate the research data. Triangulation is a technique of checking the validy of data by checking or comparing excisting data (Moleong, 2005). The data validation was done by interviewing the secretaries' managers via email: Syerli Valencia as the manager of Berdanetta Indri and Bayu Triwibowo as the manager of Agus Sumantri. The research data was analyzed using Miles and Huberman's model. Miles and Huberman in stated that the activities in qualitative data analysis are done interactively and are continuing to the extent that the data were saturated (Sugiyono, 2016). There were three phases of the research: data reduction, data presentation, and conclusion.

\section{RESULTS AND DISCUSSIONS}

\section{Results}

According to secretary from PT. Berca Handayaperkasa, in the new normal the company has implemented two systems, namely work from home and work from office and only $25 \%-50 \%$ of employees go to the office. In the new normal meeting activities are conducted online, offline will be done if needed with the limitation of people who use. For the business trip in her division have been never been done again

"Since new normal era only 25\%-50\% of the employees went to the office and the number of desks had been adjusted according to the schedule since the two work settings were implemented. For the meeting, the capacity of one room is only for four people while the bigger ones is only for seven people. 
For domestic visits, the sales and marketing team could still go on a business trip. However, since the pandemic, BOD has never been done again"

According to secretary from PT. Indofood CBP Sukses Mandiri, in the new normal her company has implemented two system but only in her division implemented the work from office system. For the meeting is conducted by online, if it is needed offline there are restrictions on the use of space. The business trip still carried out during the pandemic.

"I am currenly worked from office, but the system only applies to my division. For the meeting only 50\% of the capacity is allowed. For PCR tests were fully covered by the company, because we are assigned to go on business trips during the pandemic"

According to secretary from PT. ISTW, in the new normal his company has implemented two system. For the meeting are done by online, offline will be done if need with limitation of people who use. There are regulation to can't travel for more than $100 \mathrm{~km}$.

"Work from home or the limitation of employees who come to the office have been parts of the company regulations. For the meeting are done online. But if offline, the number of present employees cannot be more than ten people in one room. About travel ban, it is restricted to travel or homecoming for more than $100 \mathrm{~km} "$

The adaptation to new habits there are a lot of documents that accumulate because of work from home. In addition, all documents that need to be signed by the manager are submitted in full to her. But in the period of adaptation of new habits, she rarely meets with superiors so that she has difficulty asking for an autograph to the manager in addition, at the beginning of the new habit adaptation period, she has difficulty in adapting to health protocols.

"Once I enter my office, there must be documents on my desk. In the adaption of new habits, everything is fully handled by the secretary, for the health protocol at the start, I felt it was hard to adapt to the situation because previously we might not need to clean the furniture when sitting or using the desk. But now, we have to clean it up first before using it. Then, we also have to apply disinfectant and hand sanitizer"

The adaptation to new habits she has difficulty staying connected with coworkers. In the period of adaptation of new habits he can only relate to co-workers through zoom or phone. The adaptation to new habits, working hours become longer and some tasks become delayed due to work from home. At the beginning of the new habit adaptation period, Secretary experienced discomfort in implementing health protocols, but in the present is accustomed and does not interfere with work activities.

"There is indeed the feeling of distress and worries, especially when lots of tasks get delayed to be done. The number of tasks may not increase but the office hours may. It felt uncomfortable at first, but if we want to stay healthy, then following the protocols is obligatory."

Secretary of PT. Berca Handayaperkasa stated that in new normal she still performing routine tasks. However, in the period of adaptation of new habits there are some new tasks such as delivering documents that need to be signed by the manager. In addition, there are tasks that are no longer done during the pandemic such as, arranging a superior business trip and preparing snacks and rooms for meetings.

"quite enough tasks on a daily basis, such as checking documents from $P O, D O$, and contract, inputting data by system, arranging weekly schedules, lastly doing a recap and detailed checking the petty cash and expenses whether it is outflow or inflow. Besides, I have to prepare an invitation and reminder for the upcoming meeting, and other additional tasks for the preparation of closing and audit. Before the pandemic, I also have to manage the managers' business trips; from taking a hotel reservation to preparing the transportation. However, due to the pandemic, there is no such task because everything is done online now."

Secretary from PT. Indofood CBP Sukses Mandiri stated that, in new normal she still perfroming routine tasks however, in the period of adaptation of new habits there are new tasks such as manager the PCR test for the manager and prepare a room for self-quarantine for the manager.

"handle incoming and outgoing letters, archives, managing the needs for office sanitation, purchasing and setting up the office stationeries, and booking tickets for flights and hotels. Mostly, there is not much change in terms of tasks because there are still business trips. Hence, I have to manage the PCR, prepare a room for self-quarantine until the PCR result is out, write reports, print documents, and buy snacks for the meeting."

Secretary from PT. ISTW stated that in new normal he $\mathrm{s}$ in charge with matters related to covid such as encouraging health protocols, monitoring the implementation of occupational health and safety, particularly the health protocols, becoming a task force for COVID-19 or other respiratory diseases, and reporting any COVID-19 cases found in the office environment. 
"My current job descriptions are encouraging health protocols, monitoring the implementation of occupational health and safety, particularly the health protocols, becoming a task force for COVID-19 or other respiratory diseases, and reporting any COVID-19 cases found in the office environment."

Secretary of PT. Berca Handayaperkasa stated that in adaptation of new habits she is using Microsoft Office such as Word, Excel, Outlook, Lync and Access in facilitating her duties. For digital archives she use Berca Drive which has been provide by her company. In the adaptation of new habitsher company uses WebEx whis is a communication application uses as a subtitute for meeting.

"Microsoft Office that I often use are Word, Excel, Outlook, Lync, and Access. I rarely use PowerPoint, because I prefer to use Canva to design presentation slides. All meetings are conducted via online means. We use WebEx instead of Zoom. For digital archives, my company used Berca Drive for archiving, and the archives were set up to be connected to folders in local disks."

Secretary from PT. Indofood CBP Sukses Mandiri stated that, in new normal she mostly using Microsoft Office such as word, excel, power point in facilitating her duties. For digital archive she use a regular folder which is connected to the server. In adaptation of new habits her company using zoom as a subtitute for the meeting. Here is the statement of Ms. Jessica:

"Mostly using applications like Microsoft Office Word, Excel, PowerPoint, and Zoom. For archive, we have both digital and physical archives. Most of them are physical ones. We used a regular folder for the digital archives; what I meant by regular is that some are still stored in the computer's HDD, and some are archived in the server"

Secretary from PT. ISTW stated that in adaptation of new habits he moslt using microsoft office such as Excel, word, and powerpoin in facilitating his duties. For digital archive he use Citrix and Excel. Citrix is an appliciation which is made from his company. Secretary from PT. Berca Handayaperkasa stated that the skills that are indispensable in the time of adaptation of new habits are act and learn quickly and be tech-savvy. Secretary from PT. Indofood CBP Sukses Mandiri stated that the skill that indispensable in the time of adaptation of new habits is detail orianted. According to her, being detail orianted is really need it because in adaptation of new habits her tasks is to paying attention to the cleanliness, and aranging the PCR test. Secretary from PT. ISTW stated that the skill that skill that indispensable in the time of adaptation of new habits are admnistration, computer skill and English proficiency. According to him, a asecretary should have administration skills such as archive organization and management, because administration skills support the work in a company. Secretary should also be proficient in English as nowadays all technologies require ample mastery of English to do the operation. Proficiency of the language would also be extremely advantageous to communicate with foreign relations during the meetings, audits, visitations, or to create invitations and meeting results. Secretaries should also be able to operate computers as it has been a common need in the current era, thus preparing secretaries to face the upcoming digital one.

\section{Discussion}

In the new habits adaptation, the company has implemented a work from home and work from office system (Barbour et al., 2021; Islam, 2022; Li et al., 2021). This is proven by interview results with three secretaries stated that in the new habits adaptation, the company where they worked has implemented a work form home and work from office system. This regulation is in line with the Dinas Tenaga Kerja Transmigrasi dan Energi which ordered limiting the number of onsite employees to only 50\% at most and adjusting work days, office hours, shifts, and work settings. This regulation is done to implement the health protocols such as social and physical distancing (Feng \& Zhou, 2022; Tønnessen et al., 2021). This regulation is expected to prevent the spread of the covid-19 virus in the company's environtment. Social distancing could also be found in office meetings. According to the interview results, all meetings were done online during the adaptation to new habits. If offline meetings are required, there would be a limitation of the number of employees using the meeting room.

According to the interview results, since the start of new habits adaptation, secretaries encountered a change in their work setting: from previously working with the managers to working mobile. This transition affected the completion of tasks to be delayed and caused a pile-up of document yang disebabkan oleh adanya sistem work from home (Hariyani, 2021; Sarbani, 2020). At the time of adaptation new habits, the secretary also worked longer than before. According to the interview results, in the adapting to the new habits, it is quite infrequent for secretaries to meet their managers this causing the secetary difficult to ask for the manager's signature, because previously when signing documents, the manager would directly sign the documents on the same day they were given. However, the current situation required the secretaries to fully handle document signings, so that the secretary must send the important document who need to be signed to the the manager, or do it by E-sign. According to the interview results, it is know that during the new habits adaptation, it can also cause struggles to communicate with colleagues or managers. In this situation, secretaries could only rely on communication platforms to connect with their 
colleagues or managers. In the adaptation to the new habits, secretaries are also required to follow the existing health protocols. At the start of the new normal adaptation, secretaries indeed were having trouble adapting to these regulations, however secretary must be able to adapt to health protocol, because if the secretary is exposed to the covid virus, it will affecr the performamce of the manager because the secretary is the right hand of the manager who helps the manager in his duties (Purwanto et al., 2020; Sarbani, 2020).

According to the interview results, in the execution of tasks in this era, secretaries are still carrying out daily tasks while following the health protocols. The second statement as explained earlier states that the secretary is obliged to follow health protocols in carrying out the implementation of documents, preparing work agendas, maintaining cleanliness and tidiness of the office, managing petty cash, preparing for meetings, handling business trips and much more (Aw et al., 2016; Rosidah \& Arantika, 2019). In this period of adaption of new habits, secretaries has a new duties such as delivering important that want to be signed to the manager if the manager is not in the office, assigned to handle PCR tests for employees and executives, booking rooms for their self-quarantine.and secretaries are also responsible for the health protocols inside the company. According to the interview results, during the adaptation to the new normal, secretaries often use Microsoft Office to assist their daily tasks. These frequently used applications include Word, Excel, and PowerPoint. Microsoft Outlook was also used by one of the three informants to set up their manager's schedule. This finding is in line with previous research which states that secretaries utilize Microsoft Office, which provides more applications such as Microsoft Word, Excel, PowerPoint, and Outlook, to support their tasks (Astuti, 2020; Selfiana, 2018; Stroman et al., 2014). In this period of adaptation to new habits, secretaries also used communication applications that are immensely helpful to solve communication issues caused by the work-from-home policy. To communicate more easily with colleagues or managers during the adaptation, secretaries used several applications such as Zoom and WebEx (Komalasari, 2020; Stroman et al., 2014).

According to the interview results, during the adaptation to new habits, secretaries must be technologically literate as works are being shifted to online. Previous research findings also state that a secretary can take advantage of technology to help their work and become more efficient, and effective, so it is very helpful to increase office productivity (Nafiah, 2016; Rosidah \& Arantika, 2019). In that sense, it will also be easier for secretaries to develop their career with their abilities and skills to utilize technology (Dewi \& Octavia, 2017; Sarbani, 2020). During the adaptation to new habits, secretaries should also continuously learn new things. This statement reminds us that a secretary in carrying out his role must always be willing to learn new things that can make him more superior and responsive in helping to deal with problems in his company (Nafiah, 2016; Sarbani, 2020). As a secretary, you ought to always expand your potential, gain new knowledge, and other skills to make changes, improve, and to create opportunities to advance to a higher level (Rosidah and Arantika, 2019). If a secretary is open to learning new things, they will have the opportunities to maintain their existence and will not lose their place due to the pandemic and the economic crisis (Dewi \& Octavia, 2017; Sarbani, 2020).

During the new habits adaptation, secretaries are required to be detail-oriented (Nafiah, 2016; Rosidah \& Arantika, 2019). Being detail-oriented means keeping the cleanliness in the office and reminding everyone to follow the health protocol and supporting colleagues. The findings of previous studies also state that secretaries must have the skills to work carefully, because work does not work stubbornly (Selfiana, 2018; Zubaidah, 2017). The new habits different is that secretaries have to be careful in maintaining the cleanliness of the office, as well as managing the PCR tests and the health protocol of the staff and managers. In the new habit adaptation, secretary should have administration skills such as archive organization and management, because administration skills support the work in a company. Secretaries to be able to manage administration and create archives (Nafiah, 2016; Purwanto et al., 2020). This statement corresponds to who mentioned that it is essential for As a secretary, we need to have adequate administration skills because not only for handling the administration stuff to help the executives (Astuti, 2020). The administration skills acquired by secretaries can also be useful for improving the quality when completing the company tasks.

Secretaries should also be proficient in English as nowadays all technologies require ample mastery of English to do the operation. Proficiency of the language would also be extremely advantageous to communicate with foreign relations during the meetings, audits, visitations, or to create invitations and meeting results. It is important for secretaries to master English because it is not only beneficial for communicating with foreign guests or employees, but also for advancing secretaries' career and for utilizing technologies that use English as the language of instructions (Dwihartanti \& Nur Faizah, 2019; Purwanto et al., 2020). Secretaries should also be able to operate computers as it has been a common need in the current era, thus preparing secretaries to face the upcoming digital one. The similar idea which mentions that secretaries have to be able to operate computer or hardware to assist their duty as a secretary, because almost all duties of the secretary assisted by a computer and by able to operate computer secretary can be 
facilitated and can quickly complete the duties (Aw et al., 2016; Nafiah, 2016). This research is expected to help future secretarie who want to work in the period of new habit adaptation in knowing the task, application, skill and difficulties faced. For the future research, may try to add sources from various divisions.

\section{CONCLUSION}

In the new habit adaptation secretaries faced difficulties in the form of work delay due to the work from home policy which caused an accumulation of tasks, difficulties in asking for managers' signatures, less connection with colleagues, and challenging adaptation to the health protocols during the beginnings of the adaptation to new habits. In the new habit adaptation, secretaries carried their duties out while following and being responsible for the health protocols at the office. Secretaries used Microsoft Word, Excel, PowerPoint, Zoom, WebEx, and E-Arsip during the new normal. In the new habit adaptation, secretaries are expected to be technologically literate, detail-oriented, skilled at administration, and proficient in operating computers and using English.

\section{REFERENCES}

Antee, A. (2021). Student perceptions and mobile technology adoption: implications for lower-income students shifting to digital. Educational Technology Research and Development, 69(1), 191-194. https://doi.org/10.1007/s11423-020-09855-5.

Astuti, C. W. (2020). Penerapan Kompetensi Sekretaris Lulusan STARKI di Dunia Kerja. Jurnal Administrasi Dan Kesekretarisan, 5(2), 88-98. https://doi.org/10.36914/jak.v5i2.408.

Aw, S., Rosidah, R., \& Kumoro, J. (2016). Pemetaan Kompetensi, Tugas, Dan Pekerjaan Sekretaris Di Dunia Kerja. Efisiensi - Kajian Ilmu Administrasi, $13(1), \quad 11$. https://doi.org/10.21831/efisiensi.v13i1.7858.

Barbour, N., Menon, N., \& Mannering, F. (2021). A statistical assessment of work-from-home participation during different stages of the COVID-19 pandemic. Transportation Research Interdisciplinary Perspectives, 11. https://doi.org/10.1016/j.trip.2021.100441.

Cugno, M., Castagnoli, R., Büchi, G., \& Pini, M. (2022). Industry 4.0 and production recovery in the covid era. Technovation, 114. https://doi.org/10.1016/j.technovation.2021.102443.

Dewantara, J. A., \& Nurgiansah, T. H. (2020). Efektivitas Pembelajaran Daring di Masa Pandemi COVID 19 Bagi Mahasiswa Universitas PGRI Yogyakarta. Jurnal Basicedu, 5(1), 367-375. https://doi.org/10.31004/basicedu.v5i1.669.

Dewi, D. P., \& Octavia, L. (2017). Peran Sekretaris Dalam Mengelola Surat Masuk Dan Surat Keluar Pada Dinas Perpustakaan Dan Arsip Daerah Kota Tangerang Selatan. Jurnal Sekretaris Universitas Pamulang, 4(2). https://doi.org/10.32493/skr.v4i2.823.

Dwihartanti, M., \& Nur Faizah, N. (2019). Pentingnya Penguasaan Bahasa Inggris Bagi Pelaksanaan Tugas Rutin Sekretaris. Efisiensi - Kajian Ilmu Administrasi, 15(1), 28-35. https://doi.org/10.21831/efisiensi.v15i1.24483.

Feng, Y., \& Zhou, W. (2022). Work from home during the COVID-19 pandemic: An observational study based on a large geo-tagged COVID-19 Twitter dataset (UsaGeoCov19). Information Processing \& Management, 59(2). https://doi.org/10.1016/j.ipm.2021.102820.

Galanakis, C. M., Rizou, M., Aldawoud, T. M. S., Ucak, I., \& Rowan, N. J. (2021). Innovations and technology disruptions in the food sector within the COVID-19 pandemic and post-lockdown era. Trends in Food Science \& Technology, 110. https://doi.org/10.1016/j.tifs.2021.02.002.

Hanik, E. U. (2020). Self directed learning berbasis literasi digital pada masa pandemi covid-19 di Madrasah Ibtidaiyah. ELEMENTARY: Islamic Teacher Journal, 8(1), 183. https://doi.org/10.21043/elementary.v8i1.7417.

Hariyani, R. (2021). Identifikasi Kebutuhan Keterampilan Sekretaris Melalui Konten Lowongan Pekerjaan Di Masa Pandemi Covid-19. Jurnal Sekretari Dan Manajement, 19(2).

Islam, A. (2022). Work-from/at/for-home: CoVID-19 and the future of work - A critical review. Geoforum, 128. https://doi.org/10.1016/j.geoforum.2021.11.018.

Komalasari, R. (2020). Manfaat Teknologi Informasi Dan Komunikasi Di Masa Pandemi Covid 19. Tematik, 7(1), 38-50. https://doi.org/10.38204/tematik.v7i1.369.

Kristiyanti, I. (2016). Peran Komunikasi Non Verbal Dalam Menunjang Profesionalisme Sekretaris. Efisiensi - Kajian Ilmu Administrasi, 14(1). https://doi.org/10.21831/efisiensi.v14i1.16476.

Li, C., Zhang, Y., \& Chai, Y. (2021). Do spatial factors outweigh institutional factors? Changes in influencing factors of home-work separation from 2007 to 2017 in Beijing. Journal of Transport Geography, 96. 
https://doi.org/10.1016/j.jtrangeo.2021.103201.

Mardiyah, S. U. K., Kumoro, J., Kusuma, C. S. D., \& Rusdiyanto, W. (2018). Analisis Kompetensi Mahasiswa Program Studi Sekretari dalam Praktik Kerja Lapangan. Efisiensi - Kajian Ilmu Administrasi, 15(2). https://doi.org/10.21831/efisiensi.v15i2.24489.

Maulana, H. A. (2021). Psychological Impact of Online Learning during the COVID-19 Pandemic: A Case Study on Vocational Higher Education. Indonesian Journal of Learning Education and Counseling, 3(2), 130-139. https://doi.org/10.31960/ijolec.v3i2.833.

Moleong, L. J. (2005). Metode Penelitian Kualitatif. Remaja Rosdakarya.

Nafiah, D. (2016). Optimalisasi Peran Sekretaris Di Era Global Melalui Upaya Pengembangan Diri. Efisiensi Kajian Ilmu Administrasi, 13(1), 70-83. https://doi.org/10.21831/efisiensi.v13i1.7859.

Onyema, E. M. (2020). Impact of Coronavirus Pandemic on Education. Journal of Education and Practice, 11(13), 108-121. https://doi.org/10.7176/jep/11-13-12.

Prahmana, R. C. I., Hartanto, D., Kusumaningtyas, D. A., Ali, R. M., \& Muchlas. (2021). Community radio-based blended learning model: A promising learning model in remote area during pandemic era. Heliyon, 7(7), e07511. https://doi.org/10.1016/j.heliyon.2021.e07511.

Purwanto, P., Rusdiyanto, W., \& Respati, Y. A. (2020). Analysis of Secretary Job Advertisement Content for Secretarial Skills Needs. Jurnal Economia, 16(1), 44-55. https://doi.org/10.21831/economia.v16i1.29872.

Putra, R. W. P. (2021). Improving the Students' Motivation in Learning English through Google Meet during the Online Learning. English Learning Innovation, 2(1), 35-42. https://doi.org/10.22219/englie.v2i1.14605.

Rosidah, R., \& Arantika, T. (2019). Peran Teknologi untuk Pengembangan Karir Sekretaris. Efisiensi - Kajian Ilmu Administrasi, 15(1), 43-50. https://doi.org/10.21831/efisiensi.v15i1.24485.

Saifulloh, A. M., \& Darwis, M. (2020). Manajemen Pembelajaran dalam Meningkatkan Efektivitas Proses Belajar Mengajar di Masa Pandemi Covid-19. Bidayatuna: Jurnal Pendidikan Guru Mandrasah Ibtidaiyah, 3(2), 285. https://doi.org/10.36835/bidayatuna.v3i2.638.

Saputra, N., Sasanti, N., Alamsjah, F., \& Sadeli, F. (2022). Strategic role of digital capability on business agility $\begin{array}{lllll}\text { during } & \text { COVID-19 } & \text { era. } & \text { Procedia }\end{array}$ https://doi.org/10.1016/j.procs.2021.12.147.

Sarbani, Y. A. (2020). Adaptasi Kebiasaan Baru Profesi Sekretaris Di Tengah Pandemi Covid-19. Jurnal Administasi Dan Kesekretarisan, 5(2), 115-127. https://doi.org/10.36914/jak.v5i2.423.

Selfiana. (2018). Kompetensi Sekretaris Terkini Menghadapi Era Revolusi. Jurnal Administrasi Kantor, 6(2), 183-192.

Selfiana, S. (2019). Kompetensi Minimal Profesi Sekretaris Direksi Di Sepuluh Perusahaan Indonesia. Efisiensi - Kajian Ilmu Administrasi, 16(2). https://doi.org/10.21831/efisiensi.v16i2.27418.

Stroman, J., Wilson, K., \& Wauson, J. (2014). Administrative Assistant's and Secretary's Handbook (5th ed., Issue 9). AMACOM.

Sufriadi, D. (2019). Theoretical Review Of The Efficiency Of Leadership Work From The Perspective Role Of The Secretary. Jurnal Apresiasi Ekonomi, 7(2), 139-149. https://doi.org/10.31846/jae.v7i2.211.

Sugiyono. (2016). Metode Penelitian Kuantitatif, Kualitatif dan $R$ \& D. IKAPI.

Sutarna, N., Acesta, A., Cahyati, N., Giwangsa, S. F., Iskandar, D., \& Harmawati, H. (2021). Dampak Pembelajaran Daring terhadap Siswa usia 5-8 tahun. Jurnal Obsesi : Jurnal Pendidikan Anak Usia Dini, 6(1), 288-297. https://doi.org/10.31004/obsesi.v6i1.1265.

Tønnessen, Ø., Dhir, A., \& Flåten, B.-T. (2021). Digital knowledge sharing and creative performance: Work from home during the COVID-19 pandemic. Technological Forecasting and Social Change, 170. https://doi.org/10.1016/j.techfore.2021.120866.

Wuarlela, M. (2020). Variasi Metode Dan Media Pembelajaran Daring Untuk Mengakomodasi Modalitas Belajar. ARBITRER: Jurnal Pendidikan Bahasa Dan Sastra Indonesia, 2(2), 261-272. https://doi.org/10.30598/arbitrervol2no2hlm261-272.

Xu, W., Cao, H., Qin, S., \& Kong, X. (2021). Board secretary and market information efficiency: Evidence from corporate site visits. China Journal of Accounting Research, 14(3). https://doi.org/10.1016/j.cjar.2021.02.003.

Yuzulia, I. (2021). The Challenges Of Online Learning During Pandemic : Students ' V oice. Jurnal Bahasa Dan Sastra, 13(1), 8-12. https://doi.org/10.31294/w.v13i1.9759.

Zhao, J., \& Rau, P.-L. P. (2020). Merging and synchronizing corporate and personal voice agents: Comparison of voice agents acting as a secretary and a housekeeper. Computers in Human Behavior, 108. https://doi.org/10.1016/j.chb.2020.106334.

Zubaidah, S. (2017). Pentingnya Grooming Bagi Sekretaris. Jurnal Sekretari, 1(1), 7. https://doi.org/10.32493/skr.v1i1.612. 